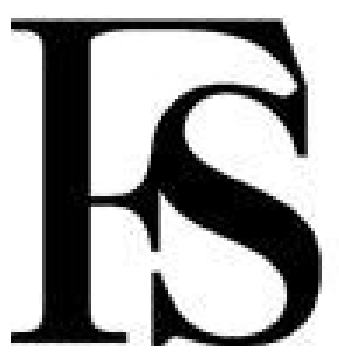

Theorizing Difference from Multiracial Feminism

Author(s): Maxine Baca Zinn and Bonnie Thornton Dill

Reviewed work(s):

Source: Feminist Studies, Vol. 22, No. 2 (Summer, 1996), pp. 321-331

Published by: Feminist Studies, Inc.

Stable URL: http://www.jstor.org/stable/3178416

Accessed: 30/11/2012 11:51

Your use of the JSTOR archive indicates your acceptance of the Terms \& Conditions of Use, available at http://www.jstor.org/page/info/about/policies/terms.jsp

JSTOR is a not-for-profit service that helps scholars, researchers, and students discover, use, and build upon a wide range of content in a trusted digital archive. We use information technology and tools to increase productivity and facilitate new forms of scholarship. For more information about JSTOR, please contact support@jstor.org. 


\section{THEORIZING DIFFERENCE FROM MULTIRACIAL FEMINISM}

\section{MAXINE BACA ZINN and BONNIE THORNTON DILL}

Women of color have long challenged the hegemony of feminisms constructed primarily around the lives of white middleclass women. Since the late 1960s, U.S. women of color have taken issue with unitary theories of gender. Our critiques grew out of the widespread concern about the exclusion of women of color from feminist scholarship and the misinterpretation of our experiences, ${ }^{1}$ and ultimately "out of the very discourses, denying, permitting, and producing difference." ${ }^{\text {"Speaking simul- }}$ taneously from "within and against" both women's liberation and antiracist movements, we have insisted on the need to challenge systems of domination, ${ }^{3}$ not merely as gendered subjects but as women whose lives are affected by our location in multiple hierarchies.

Recently, and largely in response to these challenges, work that links gender to other forms of domination is increasing. In this article, we examine this connection further as well as the ways in which difference and diversity infuse contemporary feminist studies. Our analysis draws on a conceptual framework that we refer to as "multiracial feminism." ${ }^{\text {"T }}$ This perspective is an attempt to go beyond a mere recognition of diversity and difference among women to examine structures of domination, specifically the importance of race in understanding the social construction of gender. Despite the varied concerns and multiple intellectual stances which characterize the feminisms of women of color, they share an emphasis on race as a primary force situating genders differently. It is the centrality of race, of institutionalized racism, and of struggles against racial oppression that link the various feminist perspectives within this framework. Together, they demonstrate that racial meanings offer new theoretical directions for feminist thought.

Feminist Studies 22, no. 2 (summer 1996). (C) 1996 by Feminist Studies, Inc. 


\section{TENSIONS IN CONTEMPORARY DIFFERENCE FEMINISM}

Objections to the false universalism embedded in the concept "woman" emerged within other discourses as well as those of women of color. ${ }^{5}$ Lesbian feminists and postmodern feminists put forth their own versions of what Susan Bordo has called "gender skepticism." ${ }^{16}$

Many thinkers within mainstream feminism have responded to these critiques with efforts to contextualize gender. The search for women's "universal" or "essential" characteristics is being abandoned. By examining gender in the context of other social divisions and perspectives, difference has gradually become important-even problematizing the universal categories of "women" and "men." Sandra Harding expresses the shift best in her claim that "there are no gender relations per se, but only gender relations as constructed by and between classes, races, and cultures."

Many feminists now contend that difference occupies center stage as the project of women studies today. ${ }^{8}$ According to one scholar, "difference has replaced equality as the central concern of feminist theory." Many have welcomed the change, hailing it as a major revitalizing force in U.S. feminist theory. ${ }^{10}$ But if some priorities within mainstream feminist thought have been refocused by attention to difference, there remains an "uneasy alliance" ${ }^{11}$ between women of color and other feminists.

If difference has helped revitalize academic feminisms, it has also "upset the apple cart" and introduced new conflicts into feminist studies. ${ }^{12}$ For example, in a recent and widely discussed essay, Jane Rowland Martin argues that the current preoccupation with difference is leading feminism into dangerous traps. She fears that in giving privileged status to a predetermined set of analytic categories (race, ethnicity, and class), "we affirm the existence of nothing but difference." She asks, "How do we know that for us, difference does not turn on being fat, or religious, or in an abusive relationship?"13

We, too, see pitfalls in some strands of the difference project. However, our perspectives take their bearings from social relations. Race and class differences are crucial, we argue, not as individual characteristics (such as being fat) but insofar as they are primary organizing principles of a society which lo- 
cates and positions groups within that society's opportunity structures.

Despite the much-heralded diversity trend within feminist studies, difference is often reduced to mere pluralism: a "live and let live" approach where principles of relativism generate a long list of diversities which begin with gender, class, and race and continue through a range of social structural as well as personal characteristics. ${ }^{14}$ Another disturbing pattern, which bell hooks refers to as "the commodification of difference," is the representation of diversity as a form of exotica, "a spice, seasoning that livens up the dull dish that is mainstream white culture." ${ }^{15}$ The major limitation of these approaches is the failure to attend to the power relations that accompany difference. Moreover, these approaches ignore the inequalities that cause some characteristics to be seen as "normal" while others are seen as "different" and thus, deviant.

Maria C. Lugones expresses irritation at those feminists who see only the problem of difference without recognizing difference. ${ }^{16}$ Increasingly, we find that difference is recognized. But this in no way means that difference occupies a "privileged" theoretical status. Instead of using difference to rethink the category of women, difference is often a euphemism for women who differ from the traditional norm. Even in purporting to accept difference, feminist pluralism often creates a social reality that reverts to universalizing women:

So much feminist scholarship assumes that when we cut through all of the diversity among women created by differences of racial classification, ethnicity, social class, and sexual orientation, a "universal truth" concerning women and gender lies buried underneath. But if we can face the scary possibility that no such certainty exists and that persisting in such a search will always distort or omit someone's experiences, with what do we replace this old way of thinking? Gender differences and gender politics begin to look very different if there is no essential woman at the core. ${ }^{17}$

\section{WHAT IS MULTIRACIAL FEMINISM?}

A new set of feminist theories have emerged from the challenges put forth by women of color. Multiracial feminism is an evolving body of theory and practice informed by wide-ranging intellectual traditions. This framework does not offer a singular or unified feminism but a body of knowledge situating 
women and men in multiple systems of domination. U.S. multiracial feminism encompasses several emergent perspectives developed primarily by women of color: African Americans, Latinas, Asian Americans, and Native Americans, women whose analyses are shaped by their unique perspectives as "outsiders within"-marginal intellectuals whose social locations provide them with a particular perspective on self and society. ${ }^{18} \mathrm{Al}-$ though U.S. women of color represent many races and ethnic backgrounds-with different histories and cultures-our feminisms cohere in their treatment of race as a basic social division, a structure of power, a focus of political struggle, and hence a fundamental force in shaping women's and men's lives.

This evolving intellectual and political perspective uses several controversial terms. While we adopt the label "multiracial," other terms have been used to describe this broad framework. For example, Chela Sandoval refers to "U.S. Third World feminisms," ${ }^{19}$ while other scholars refer to "indigenous feminisms." In their theory text-reader, Alison M. Jagger and Paula M. Rothenberg adopt the label "multicultural feminism." ${ }^{\text {"20 }}$

We use "multiracial" rather than "multicultural" as a way of underscoring race as a power system that interacts with other structured inequalities to shape genders. Within the U. S. context, race, and the system of meanings and ideologies which accompany it, is a fundamental organizing principle of social relationships. ${ }^{21}$ Race affects all women and men, although in different ways. Even cultural and group differences among women are produced through interaction within a racially stratified social order. Therefore, although we do not discount the importance of culture, we caution that cultural analytic frameworks that ignore race tend to view women's differences as the product of group-specific values and practices that often result in the marginalization of cultural groups which are then perceived as exotic expressions of a normative center. Our focus on race stresses the social construction of differently situated social groups and their varying degrees of advantage and power. Additionally, this emphasis on race takes on increasing political importance in an era where discourse about race is governed by color-evasive language ${ }^{22}$ and a preference for individual rather than group remedies for social inequalities. Our analyses insist upon the primary and pervasive nature of race 
in contemporary U.S. society while at the same time acknowledging how race both shapes and is shaped by a variety of other social relations.

In the social sciences, multiracial feminism grew out of socialist feminist thinking. Theories about how political economic forces shape women's lives were influential as we began to uncover the social causes of racial ethnic women's subordination. But socialist feminism's concept of capitalist patriarchy, with its focus on women's unpaid (reproductive) labor in the home failed to address racial differences in the organization of reproductive labor. As feminists of color have argued, "reproductive labor has divided along racial as well as gender lines, and the specific characteristics have varied regionally and changed over time as capitalism has reorganized." ${ }^{23}$ Despite the limitations of socialist feminism, this body of literature has been especially useful in pursuing questions about the interconnections among systems of domination. ${ }^{24}$

Race and ethnic studies was the other major social scientific source of multiracial feminism. It provided a basis for comparative analyses of groups that are socially and legally subordinated and remain culturally distinct within U.S. society. This includes the systematic discrimination of socially constructed racial groups and their distinctive cultural arrangements. Historically, the categories of African American, Latino, Asian American, and Native American were constructed as both racially and culturally distinct. Each group has a distinctive culture, shares a common heritage, and has developed a common identity within a larger society that subordinates them. ${ }^{25}$

We recognize, of course, certain problems inherent in an uncritical use of the multiracial label. First, the perspective can be hampered by a biracial model in which only African Americans and whites are seen as racial categories and all other groups are viewed through the prism of cultural differences. Latinos and Asians have always occupied distinctive places within the racial hierarchy, and current shifts in the composition of the U.S. population are racializing these groups anew. ${ }^{26}$

A second problem lies in treating multiracial feminism as a single analytical framework, and its principle architects, women of color, as an undifferentiated category. The concepts "multiracial feminism," "racial ethnic women," and "women of color" 
"homogenize quite different experiences and can falsely universalize experiences across race, ethnicity, sexual orientation, and age." ${ }^{27}$ The feminisms created by women of color exhibit a plurality of intellectual and political positions. We speak in many voices, with inconsistencies that are born of our different social locations. Multiracial feminism embodies this plurality and richness. Our intent is not to falsely universalize women of color. Nor do we wish to promote a new racial essentialism in place of the old gender essentialism. Instead, we use these concepts to examine the structures and experiences produced by intersecting forms of race and gender.

It is also essential to acknowledge that race is a shifting and contested category whose meanings construct definitions of all aspects of social life. ${ }^{28}$ In the United States it helped define citizenship by excluding everyone who was not a white, male property owner. It defined labor as slave or free, coolie or contract, and family as available only to those men whose marriages were recognized or whose wives could immigrate with them. Additionally, racial meanings are contested both within groups and between them. ${ }^{29}$

Although definitions of race are at once historically and geographically specific, they are also transnational, encompassing diasporic groups and crossing traditional geographic boundaries. Thus, while U.S. multiracial feminism calls attention to the fundamental importance of race, it must also locate the meaning of race within specific national traditions.

\section{THE DISTINGUISHING FEATURES OF MULTIRACIAL FEMINISM}

By attending to these problems, multiracial feminism offers a set of analytic premises for thinking about and theorizing gender. The following themes distinguish this branch of feminist inquiry.

First, multiracial feminism asserts that gender is constructed by a range of interlocking inequalities, what Patricia Hill Collins calls a "matrix of domination." ${ }^{130}$ The idea of a matrix is that several fundamental systems work with and through each other. People experience race, class, gender, and sexuality differently depending upon their social location in the structures 
of race, class, gender, and sexuality. For example, people of the same race will experience race differently depending upon their location in the class structure as working class, professional managerial class, or unemployed; in the gender structure as female or male; and in structures of sexuality as heterosexual, homosexual, or bisexual.

Multiracial feminism also examines the simultaneity of systems in shaping women's experience and identity. Race, class, gender, and sexuality are not reducible to individual attributes to be measured and assessed for their separate contribution in explaining given social outcomes, an approach that Elizabeth Spelman calls "popbead metaphysics," where a woman's identity consists of the sum of parts neatly divisible from one anoth$\mathrm{er}^{31}$ The matrix of domination seeks to account for the multiple ways that women experience themselves as gendered, raced, classed, and sexualized.

Second, multiracial feminism emphasizes the intersectional nature of hierarchies at all levels of social life. Class, race, gender, and sexuality are components of both social structure and social interaction. Women and men are differently embedded in locations created by these cross-cutting hierarchies. As a result, women and men throughout the social order experience different forms of privilege and subordination, depending on their race, class, gender, and sexuality. In other words, intersecting forms of domination produce both oppression and opportunity. At the same time that structures of race, class, and gender create disadvantages for women of color, they provide unacknowledged benefits for those who are at the top of these hierarchies-whites, members of the upper classes, and males. Therefore, multiracial feminism applies not only to racial ethnic women but also to women and men of all races, classes, and genders.

Third, multiracial feminism highlights the relational nature of dominance and subordination. Power is the cornerstone of women's differences. ${ }^{32}$ This means that women's differences are connected in systematic ways. ${ }^{33}$ Race is a vital element in the pattern of relations among minority and white women. As Linda Gordon argues, the very meanings of being a white woman in the United States have been affected by the existence of subordinated women of color: "They intersect in conflict and in 
occasional cooperation, but always in mutual influence."134

Fourth, multiracial feminism explores the interplay of social structure and women's agency. Within the constraints of race, class, and gender oppression, women create viable lives for themselves, their families, and their communities. Women of color have resisted and often undermined the forces of power that control them. From acts of quiet dignity and steadfast determination to involvement in revolt and rebellion, women struggle to shape their own lives. Racial oppression has been a common focus of the "dynamic of oppositional agency" of women of color. As Chandra Talpade Mohanty points out, it is the nature and organization of women's opposition which mediates and differentiates the impact of structures of domination. ${ }^{35}$

Fifth, multiracial feminism encompasses wide-ranging methodological approaches, and like other branches of feminist thought, relies on varied theoretical tools as well. Ruth Frankenberg and Lata Mani identify three guiding principles of inclusive feminist inquiry: "building complex analyses, avoiding erasure, specifying location. ${ }^{136}$ In the last decade, the opening up of academic feminism has focused attention on social location in the production of knowledge. Most basically, research by and about marginalized women has destabilized what used to be considered as universal categories of gender. Marginalized locations are well suited for grasping social relations that remained obscure from more privileged vantage points. Lived experience, in other words, creates alternative ways of understanding the social world and the experience of different groups of women within it. Racially informed standpoint epistemologies have provided new topics, fresh questions, and new understandings of women and men. Women of color have, as Norma Alarçon argues, asserted ourselves as subjects, using our voices to challenge dominant conceptions of truth. ${ }^{37}$

Sixth, multiracial feminism brings together understandings drawn from the lived experiences of diverse and continuously changing groups of women. Among Asian Americans, Native Americans, Latinas, and Blacks are many different national cultural and ethnic groups. Each one is engaged in the process of testing, refining, and reshaping these broader categories in its own image. Such internal differences heighten awareness of and sensitivity to both commonalities and differences, serving 
as a constant reminder of the importance of comparative study and maintaining a creative tension between diversity and universalization.

\section{DIFFERENCE AND TRANSFORMATION}

Efforts to make women's studies less partial and less distorted have produced important changes in academic feminism. Inclusive thinking has provided a way to build multiplicity and difference into our analyses. This has led to the discovery that race matters for everyone. White women, too, must be reconceptualized as a category that is multiply defined by race, class, and other differences. As Ruth Frankenberg demonstrates in a study of whiteness among contemporary women, all kinds of social relations, even those that appear neutral, are, in fact, racialized. Frankenberg further complicates the very notion of a unified white identity by introducing issues of Jewish identity. ${ }^{38}$ Therefore, the lives of women of color cannot be seen as a variation on a more general model of white American womanhood. The model of womanhood that feminist social science once held as "universal" is also a product of race and class.

When we analyze the power relations constituting all social arrangements and shaping women's lives in distinctive ways, we can begin to grapple with core feminist issues about how genders are socially constructed and constructed differently. Women's difference is built into our study of gender. Yet this perspective is quite far removed from the atheoretical pluralism implied in much contemporary thinking about gender.

Multiracial feminism, in our view, focuses not just on differences but also on the way in which differences and domination intersect and are historically and socially constituted. It challenges feminist scholars to go beyond the mere recognition and inclusion of difference to reshape the basic concepts and theories of our disciplines. By attending to women's social location based on race, class, and gender, multiracial feminism seeks to clarify the structural sources of diversity. Ultimately, multiracial feminism forces us to see privilege and subordination as interrelated and to pose such questions as: How do the existences and experiences of all people-women and men, different 
racial-ethnic groups, and different classes-shape the experiences of each other? How are those relationships defined and enforced through social institutions that are the primary sites for negotiating power within society? How do these differences contribute to the construction of both individual and group identity? Once we acknowledge that all women are affected by the racial order of society, then it becomes clear that the insights of multiracial feminism provide an analytical framework, not solely for understanding the experiences of women of color but for understanding all women, and men, as well.

\section{NOTES}

$\rightarrow$ Maxine Baca Zinn, Lynn Weber Cannon, Elizabeth Higginbotham, and Bonnie Thornton Dill, "The Costs of Exclusionary Practices in Women's Studies," Signs 11 (winter 1986): 290-303.

2. Chela Sandoval, "U.S. Third World Feminism: The Theory and Method of Oppositional Consciousness in the Postmodern World," Genders (spring 1991): 1-24.

3. Ruth Frankenberg and Lata Mani, "Cross Currents, Crosstalk: Race, 'Postcoloniality,' and the Politics of Location," Cultural Studies 7 (May 1993): 292-310.

4. We use the term "multiracial feminism" to convey the multiplicity of racial groups and feminist perspectives.

5. A growing body of work on difference in feminist thought now exists. Although we cannot cite all the current work, the following are representative: Michèle Barrett, "The Concept of Difference," Feminist Review 26 (July 1987): 29-42; Christina Crosby, "Dealing with Difference," in Feminists Theorize the Political, ed. Judith Butler and Joan W. Scott (New York: Routledge, 1992), 130-43; Elizabeth Fox-Genovese, "Difference, Diversity, and Divisions in an Agenda for the Women's Movement," in Color, Class, and Country: Experiences of Gender, ed. Gay Young and Bette J. Dickerson (London: Zed Books, 1994), 232- $\rightarrow$ Nancy A. Hewitt, "Compounding Differences," Feminist Studies 18 (summer 1992): 313-26; Maria C. Lugones, "On the Logic of Feminist Pluralism," in Feminist Ethics, ed. Claudia Card (Lawrence: University of Kansas Press, 1991), 35-44; Rita S. Gallin and Anne Ferguson, "The Plurality of Feminism: Rethinking 'Difference,'" in The Woman and International Development Annual (Boulder: Westview Press, 1993), 3: 1-16; and Linda Gordon, "On Difference," Genders 10 (spring 1991): 91-111.

6. Susan Bordo, "Feminism, Postmodernism, and Gender Skepticism," in Feminism / Postmodernism, ed. Linda J. Nicholson (London: Routledge, 1990), 133-56.

7. Sandra G. Harding, Whose Science? Whose Knowledge? Thinking from Women's Lives (Ithaca: Cornell University Press, 1991), 179.

8. Crosby, 131.

9. Fox-Genovese, 232.

10. Faye Ginsberg and Anna Lowenhaupt Tsing, Introduction to Uncertain Terms, Negotiating Gender in American Culture, ed. Faye Ginsberg and Anna Lowenhaupt Tsing (Boston: Beacon Press, 1990), 3.

11. Sandoval, 2.

12. Sandra Morgan, "Making Connections: Socialist-Feminist Challenges to Marx- 
ist Scholarship," in Women and a New Academy: Gender and Cultural Contexts, ed. Jean F. O'Barr (Madison: University of Wisconsin Press, 1989), 149.

$\rightarrow$ Jane Rowland Martin, "Methodological Essentialism, False Difference, and Other Dangerous Traps," Signs 19 (spring 1994): 647.

14. Barrett, 32 .

15. bell hooks, Black Looks: Race and Representation (Boston: South End Press, 1992), 21.

16. Lugones, 35-44.

17. Patricia Hill Collins, Foreword to Women of Color in U.S. Society, ed. Maxine Baca Zinn and Bonnie Thornton Dill (Philadelphia: Temple University Press, 1994), xv.

$\rightarrow$ Patricia Hill Collins, "Learning from the Outsider Within: The Sociological Significance of Black Feminist Thought," Social Problems 33 (December 1986): 514-32.

19. Sandoval, 1.

20. Alison M. Jagger and Paula S. Rothenberg, Feminist Frameworks: Alternative Theoretical Accounts of the Relations between Women and Men, 3d ed. (New York: McGraw-Hill, 1993).

21. Michael Omi and Howard Winant, Racial Formation in the United States: From the 1960s to the 1980s, 2d ed. (New York: Routledge, 1994).

22. Ruth Frankenberg, The Social Construction of Whiteness: White Women, Race Matters (Minneapolis: University of Minnesota Press, 1993).

$: \rightarrow$ Evelyn Nakano Glenn, "From Servitude to Service Work: Historical Continuities in the Racial Division of Paid Reproductive Labor," Signs 18 (autumn 1992): 3. See also Bonnie Thornton Dill, "Our Mothers' Grief: Racial-Ethnic Women and the Maintenance of Families," Journal of Family History 13, no. 4 (1988): 415-31.

24. Morgan, 146.

25. Maxine Baca Zinn and Bonnie Thornton Dill, "Difference and Domination," in Women of Color in U.S. Society, 11-12.

26. See Omi and Winant, 53-76, for a discussion of racial formation.

27. Margaret L. Andersen and Patricia Hill Collins, Race, Class, and Gender: An Anthology (Belmont, Calif.: Wadsworth, 1992), xvi.

28. Omi and Winant.

29. Nazli Kibria, "Migration and Vietnamese American Women: Remaking Ethnicity," in Women of Color in U.S. Society, 247-61.

30. Patricia Hill Collins, Black Feminist Thought: Knowledge, Consciousness, and the Politics of Empowerment (Boston: Unwin Hyman, 1990).

31. Elizabeth Spelman, Inessential Women: Problems of Exclusion in Feminist Thought (Boston: Beacon Press, 1988), 136.

32. Several discussions of difference make this point. See Baca Zinn and Dill, 10; Gordon, 106; and Lynn Weber, in the "Symposium on West and Fenstermaker's 'Doing Difference,'" Gender \& Society 9 (August 1995): 515-19.

33. Glenn, 10.

34. Gordon, 106.

35. Chandra Talpade Mohanty, "Cartographies of Struggle: Third World Women and the Politics of Feminism," in Third World Women and the Politics of Feminism, ed. Chandra Talpade Mohanty, Ann Russo, and Lourdes Torres (Bloomington: Indiana University Press, 1991), 13.

36. Frankenberg and Mani, 306.

37. Norma Alarçon, "The Theoretical Subject(s) of This Bridge Called My Back and Anglo-American Feminism," in Making Face, Making Soul, Haciendo Caras: Creative and Critical Perspectives by Women of Color, ed. Gloria Anzaldúa (San Francisco: Aunt Lute, 1990), 356.

38. Frankenberg. See also Evelyn Torton Beck, "The Politics of Jewish Invisibility," NWSA Journal (fall 1988): 93-102. 